\title{
Especulação financeira e capitalismo contemporâneo: uma proposição teórica a partir de Marx
}

\author{
Mauricio de Souza Sabadini
}

\begin{abstract}
Resumo
No contexto da análise das fases de circulação e produção capitalista, o objetivo principal deste artigo é o de enfatizar que o processo de autonomização das formas funcionais do capital, com base na teoria do valor-trabalho de Marx e caracterizado principalmente pelo capital fictício, é um forte instrumento para explicar algumas transformações verificadas no capitalismo contemporâneo. Destaque especial para as crises capitalistas recentes e para o intenso processo de especulação financeira.
\end{abstract}

Palavras-chave: Especulação financeira; Capital fictício; Crise; Capitalismo contemporâneo; Teoria Marxista.

\begin{abstract}
Financial speculation and contemporary capitalism: a theoretical proposition based on Marx

Regarding the analysis of the stages of capitalist production and circulation, the main objective of this article is to emphasize that the self-expansion process of the functional forms of capital, is a tool that effectively explains the changes observed in contemporary capitalism. This process takes place under the foundations of Marx's value theory, and is primarily characterized by fictitious capital. Particular attention is given to the recent capitalist crises and the intense financial speculation process.
\end{abstract}

Key words: Financial speculation; Fictitious capital; Crisis; Contemporary capitalism; Marxist theory.

JEL B14, E51, G10.

\section{Introdução}

Comuns são as críticas feitas diretamente a Marx e à teoria Marxista quanto a sua utilidade para interpretar as constantes mudanças sofridas pelo capitalismo contemporâneo, tanto no que se refere aos aspectos produtivos mas, sobretudo, quanto aos financeiros. Sugerindo por vezes que o método adotado pelo autor seja obscuro e distante da realidade dos fatos, alguns chegam mesmo a propor uma inversão metodológica na intenção de, pretensamente, melhor utilizá-lo na compreensão dos fenômenos da sociedade atual. Robinson (1971), por exemplo, no capítulo sobre a teoria do valor, afirma que existe "um dogmatismo simplificador

\footnotetext{
* Trabalho recebido em 8 de abril de 2011 e aprovado em 12 de novembro de 2012.

** Professor do Departamento de Economia e do Programa de Pós-Graduação em Política Social (PPGPS) da Universidade Federal do Espírito Santo (UFES). Tutor do grupo PET-Economia/UFES (SESU/MEC). E-mail: mauricio.sabadini@ufes.br. Agradeço aos (às) pareceristas anônimos(as) pelos valiosos comentários e sugestões.
} 
do livro I de $O$ Capital até as fórmulas complexas do livro III. Mas, se partirmos do livro III, a dificuldade do percurso é bem menor".

De fato, o método dialético exige uma construção constante e é exatamente a partir dele que a verdadeira natureza do capitalismo é revelada. Por isso, para nós, é impossível desmistificar as categorias do Livro III, em particular o capital portador de juros e o capital fictício - centrais na análise concreta do capitalismo contemporâneo -, se nós não entendermos a essência das categorias do Livro I. Nesse caso, a inversão proposta por Robinson revela, no mínimo, uma incompreensão da importância da teoria do valor em Marx ${ }^{1}$.

Além do mais, sabemos que o capitalismo está sempre à procura de novas formas de acumulação, provocando transformações no ciclo do capital global (D M - D'), quer seja na esfera da produção ou da circulação. A nosso ver, uma das características mais importantes do capitalismo atual é o crescimento da esfera financeira do capital, que se desenvolve de uma maneira ainda mais imbricada com a produção real. As fases produtivas e financeiras fazem parte da natureza capitalista e estão, evidentemente, em estreita ligação no sistema econômico. Hilferding (1985) mesmo desenvolveu o conceito de "capital financeiro", colocando em evidência a ligação entre os circuitos financeiro e produtivo das mercadorias, numa época na qual o capitalismo estava mais orientado para o capital produtivo. Acontece que esse conceito, a nosso ver, não é totalmente pertinente na atualidade para apreender o processo de autonomização das formas funcionais do capital e, consequentemente, da desmaterialização do dinheiro que se traduz pela intensa multiplicação de ativos financeiros no interior do sistema econômico, caracterizados principalmente por suas transações fictícias ${ }^{2}$.

(1) Se seguirmos as observações de Robinson, a teoria do valor e o processo de compreensão da mercadoria, dinheiro e capital, constantes nos primeiros capítulos do Livro I de $O$ Capital, ficam de fora das análises ou ao menos deixam de ser centrais, comprometendo, a nosso ver, a interpretação dos fenômenos. Para outra visão crítica das obras de Robinson ver Rosdolsky (2001), especialmente o capítulo 23.

(2) Acreditamos que após Hilferding (1985), o termo "capital financeiro" vem sendo utilizado de forma insuficiente para caracterizar a atual etapa da acumulação capitalista influenciada fortemente pela esfera financeira do capital e seus aspectos de remuneração fictícia. Vejamos uma forma em que o referido autor trata o termo: "chamo de capital financeiro o capital bancário, portanto o capital em forma de dinheiro que, desse modo, é na realidade transformado em capital industrial. Mantém sempre a forma de dinheiro ante os proprietários, é aplicado por eles em forma de capital monetário - de capital rendoso - e sempre pode ser retirado por eles em forma de dinheiro. Mas, na verdade, a maior parte do capital investido dessa forma nos bancos é transformado em capital industrial, produtivo (meios de produção e força de trabalho) e imobilizado no processo de produção. Uma parte cada vez maior do capital empregado na indústria é capital financeiro, capital à disposição dos bancos e, pelos industriais. O capital financeiro desenvolveu-se com o desenvolvimento da sociedade anônima e alcança o seu apogeu com a monopolização da indústria" (ibid, p. 219). Como veremos ao longo deste trabalho, esse conceito, que foi seguido por Lénine (1954) e pela ampla maioria dos autores contemporâneos, se aproxima, a nosso ver, mais das análises que tratam do conceito de capital portador de juros em Marx do que propriamente do de capital fictício, esse sim central para compreender os movimentos especulativos atuais. Para maiores detalhes acerca dessa e de outras interpretações sobre o conceito de capital financeiro, consultar Pinto (1994) e Sabadini (2012). 
É no contexto da análise das fases de circulação e produção capitalista que se desenvolve o objetivo principal deste artigo, qual seja: enfatizar que o processo de autonomização das formas funcionais do capital, com base na teoria do valortrabalho de Marx e caracterizado principalmente pelo capital fictício, é fundamental para explicar as transformações verificadas no capitalismo contemporâneo, sobretudo aquelas relacionadas às crises capitalistas que se manifestam atualmente sob a forma de crises financeiras com fortes movimentos especulativos. A hipótese central é a de que a dinâmica da acumulação capitalista atual está fundamentada na autonomia relativa do capital fictício no circuito de valorização do capital, na qual, ao mesmo tempo em que possui certo grau de autonomia face ao capital produtivo, mantém com o mesmo estreitas relações de dependência ${ }^{3}$.

No centro da análise, a teoria do valor-trabalho em Marx. Entendemos que a riqueza dessa teoria nos dá a possibilidade de avançar sobre as imbricações existentes entre as categorias valor-trabalho e dinheiro, no sentido de compreender a sequência atual do processo de transformação da esfera financeira do capital, sob forte influência do capital fictício, e da relação dialética de dependência e de autonomia em relação ao capital produtivo.

Portanto, o ponto de partida de nossa interpretação será a mercadoria e o dinheiro, os objetos mais simples e, ao mesmo tempo, os mais complexos da natureza capitalista. Nós justificamos essa escolha: eles fazem parte da base e mesmo do desenvolvimento do capitalismo, desde seu aspecto mercantilista até seu caráter industrial e financeiro. O desenvolvimento do dinheiro e autonomização das formas funcionais do capital permitirão, então, elucidar as ligações estreitas entre as esferas da circulação e da produção capitalista.

\section{A Santíssima Trindade do capital - a mercadoria, o valor e o dinheiro - e sua relação incestuosa com o trabalho}

A nosso ver, a mercadoria e o dinheiro são as formas de existência do capital. Sua substância é formada pelo valor-trabalho, a fonte que confere o

(3) Em consonância com nossa tese, Mollo (1989, p. 67) afirma que: "a autonomia da circulação em relação à produção é então explicitada no capital fictício em três sentidos: a) referindo-se ao capital financeiro como uma função de um capital particular, o capital fictício, tal como o capital financeiro, está restrito à fase de circulação, uma das fases que define o ciclo completo de reprodução do capital, separada da fase da produção; b) derivado do capital de empréstimos produtor de juros [capital portador de juros]: tendo este um preço sem relação direta com o valor, o capital fictício não tem mais esta relação; c) como uma forma através da qual o capital monetário é emprestado levando em consideração que a acumulação do capital monetário não é sempre um índice de acumulação de capital real. O desenvolvimento do capital fictício pode se reproduzir sem estreita relação com a acumulação de capital real. Tal autonomia faz do capital fictício um caso real de divergência entre preços e valores, quer dizer uma expressão da autonomia da circulação em relação à produção" (NT). Onde: NT = nossa tradução. 
movimento e as contradições das formas sociais capitalistas. Sem uma percepção clara dessas categorias, as mutações do capitalismo não podem ser bem compreendidas. Brunhoff $(1972,1976)$ indica algumas razões que determinam o interesse pela noção da mercadoria e do valor de troca. Uma delas é que Marx considera, em sua análise, a questão da acumulação primitiva, ou seja, ele não parte de um estoque dado de mercadorias acumuladas, mas, ao contrário, concentra suas avaliações sobre o desenvolvimento histórico do comércio, dos bancos e da circulação das mercadorias, que conduziu a transformação do dinheiro em capital. Além do mais, a concepção Marxista do dinheiro é importante em função de sua própria articulação com o modo de produção capitalista, já que constitui uma das engrenagens do sistema e expressa uma relação social de produção.

Percebemos que a autora já apontava para a necessidade do entendimento do dinheiro como integrante do desenvolvimento de uma mercadoria especial no capitalismo. Uma mercadoria que além de ser aceita por todos, poderia também representar o valor de troca das transações entre as mercadorias. Uma mercadoria que, como valor, poderia ser equivalente e, ao mesmo tempo, como equivalente, ter a propriedade de ser trocada. É necessário que elas possam ser trocadas a partir de uma terceira, um símbolo que representa as relações do valor de troca entre elas mesmas, que pode ser o signo do valor mais desenvolvido, quer dizer, ser o símbolo do tempo de trabalho.

De maneira mais primitiva, a mercadoria aparece ao mundo como uma "coisa" derivada da natureza e, portanto, objeto de consumo dos indivíduos; ao mesmo tempo, ela apresenta alguns elementos místicos. Mas, na sua primeira aparência, "aos olhos dos indivíduos", ela é um simples objeto, um elemento material, um simples produto utilizado que contém valor de uso. Essa visão não é falsa. A mercadoria é, verdadeiramente, um objeto que possibilita satisfazer diversas necessidades, ela fornece um valor de uso aos indivíduos, sua utilidade forma o conteúdo material da riqueza, viabilizando o consumo e permitindo a realização de uma satisfação particular. Como produtor de valores de uso, o trabalho é um elemento central da existência humana. Trabalho útil/concreto, e de diferente qualidade, ele personifica e medeia a circulação material entre o homem e a natureza. Para ser mercadoria, o valor de uso deve não somente produzir valores de uso, mas também valores de uso para outras pessoas a partir de sua venda no mercado.

Ao mesmo tempo, a mercadoria tem um valor de troca que aparece, segundo Marx (1948), como a relação quantitativa que muda invariavelmente no tempo e no espaço e que legitima as trocas de diferentes objetos no mercado. Se, como valor de uso, as mercadorias aparecem portadoras de diferentes qualidades, como valor de troca, elas têm várias quantidades. Então, elas podem ser trocadas umas contra 
as outras. De fato, uma mercadoria que se apresenta como valor de troca tem "algo" de diferente, no fundo ela exterioriza uma relação universal que é aceita por todos como a mercadoria geral. Na verdade, os vínculos entre as mercadorias se explicam pelas relações que elas contêm com o valor-trabalho; com efeito, as mercadorias estão relacionadas a um quantum determinado de trabalho, de tempo de trabalho social que está na origem da criação da riqueza e que contém o conjunto das atividades sociais humanas incorporadas no capitalismo. Então, a substância do valor é o trabalho, sua grandeza é determinada pelo tempo de trabalho e sua forma é adotada a partir do valor de troca.

A partir desses elementos, já podemos afirmar que, no valor de uso, o mistério da mercadoria desaparece, já que ela tem a capacidade de satisfazer as necessidades humanas e recebe essa propriedade como produto do trabalho humano concreto. Sua utilidade permite as trocas no mercado para completar o ciclo de rotação do capital, vital, portanto, para a reprodução capitalista. Então, o verdadeiro caráter misterioso das mercadorias reside no fato de que elas refletem as características sociais do trabalho incorporadas no processo produtivo. Elas revelam a relação social existente entre os seres humanos na produção, por isso a evidência de que "o trabalho não produz somente mercadorias; ele se reproduz e produz o trabalhador [a força de trabalho] como mercadoria..." (NT) (Marx, 1972, p. 54). É assim que os produtos do trabalho se transformam em mercadorias, “coisas" metafísicas ou sociais (Marx, 1983, p. 71).

Essas afirmações de Marx indicam que as mercadorias apresentam várias formas complementares, constituindo um verdadeiro processo dialético, de representações concretas (utilidade) e abstratas (relação social), representando relações entre pessoas, contornadas pelo caráter social do trabalho, ligadas umas às outras pela relação de produção das mercadorias, representantes sociais da realidade econômica e social, como dizia Roubine (1978).

Como sabemos, Marx conclui a análise afirmando que a substância comum que permite as trocas entre as mercadorias é o valor-trabalho. A essência do valor ilustra a relação social, a expressão das relações sociais entre indivíduos através das mercadorias. "Qualquer coisa de comum que se mostra na relação das trocas ou no valor de trocas das mercadorias é como consequência seu valor; e um valor de uso, ou um artigo qualquer, não tem um valor a não ser que trabalho humano seja materializado nele" (NT) (Marx, 1948, p. 54). Então, chegamos à conclusão de que uma mercadoria tem valor porque ela é uma cristalização do trabalho social, a grandeza de seu valor, seu valor relativo, depende da quantidade dessa substância social que ela possui, ou seja, depende da quantidade relativa de trabalho necessário à sua produção (Marx, 1969). 
Mas, o processo de substantivação do valor não cessa ${ }^{4}$. O capitalismo é um sistema dinâmico por natureza. Ele cria novas formas de acumulação, ele muda para manter e amplificar suas relações de dominação. Em sua configuração histórica, a própria mercadoria evolui; como mercadoria, ela se transformou em relação ao movimento do capitalismo; o valor-trabalho se materializou em nova forma: é a encarnação sob a forma dinheiro de uma relação cada vez mais complexa e incestuosa com o trabalho.

Nesse sentido, o dinheiro passa a ser uma mercadoria especial no capitalismo; uma mercadoria que é aceita por todos e que representa o valor de troca nas transações. Uma mercadoria que, como valor, pode ser equivalente e, enquanto equivalente, ter a propriedade de ser trocada; um símbolo que representa as relações dos valores de troca entre elas mesmas, que pode ser o signo do valor num estágio mais desenvolvido, o que quer dizer ser o símbolo do tempo de trabalho. "De fato, a mercadoria que é utilizada como mediadora das trocas é transformada pouco a pouco em dinheiro, em um símbolo; desde que isto é feito, um símbolo dela mesma pode substituí-la. Ela torna-se então um signo consciente do valor de troca" (NT) (Marx, 1980, p. 79).

Da forma simples do valor à forma dinheiro, Marx descreve todo o processo de sua substantivação, em que a forma mais desenvolvida nesse momento, representada pelo dinheiro, passa a ser o representante máximo do valor; ela é "a forma de manifestação do valor, a encarnação social do trabalho humano" (NT) (Marx, 1948). O poder representativo do dinheiro é fortemente misterioso, também contraditório e, portanto, dialético ${ }^{5}$.

Com a forma dinheiro - um representante mais desenvolvido do valor - o fetiche e a substantivação do valor se desenvolvem significativamente, passando a um nível mais elevado de abstração; na representação contraditória e profunda da natureza do sistema capitalista, o dinheiro expressa o signo das relações sociais, políticas e econômicas entre os indivíduos. Ele é um dos instrumentos de dominação, de exploração, de reificação das relações humanas identificadas ao caráter inanimado e quantitativo das mercadorias.

(4) "De simples adjetivo das mercadorias, o valor converte-se em substantivo no ciclo do capital. Quando o valor não é mais simples valor, mas valor-capital, enfrentamo-nos com a substantivação do valor. Marx dedica somente uma única passagem ao assunto no capítulo IV do livro I de O Capital e algumas outras no capítulo primeiro do livro II" (Carcanholo; Nakatani, 1999, p. 289).

(5) Segundo Marx (1972, p. 102), "o dinheiro possuindo a qualidade de tudo comprar, possuindo a qualidade de se apropriar de todos os objetos é, portanto, o objeto dominante. A universalidade de sua qualidade é o seu poder sem-limite (...) O dinheiro é o intermediário entre a necessidade e o objeto, entre a vida e o meio de subsistência do homem" (NT). 
O dinheiro deposita, nas mercadorias, a representação do valor e representa a encarnação do trabalho humano. Aqui, se localiza a magia, o mistério, o enigma do fetiche do dinheiro. A relação incestuosa entre mercadoria, valor, dinheiro e trabalho se conclui. São os primeiros passos em direção ao capital.

\section{0 capital e a autonomização de suas formas funcionais}

O capitalismo sempre desenvolveu novas formas funcionais, metamorfoseando invariavelmente todas as relações de poder, de trocas e mesmo de classes no seio de sua sociedade. Seu objetivo único é valorizar o valor, adquirir mais-valia, buscar constantemente novas formas de acumulação. Nesse sentido, a discussão sobre o que é o capital passa a ser de extrema relevância, sobretudo na teoria Marxista.

A palavra capital é objeto de várias interpretações no seio das ciências humanas ${ }^{6}$. Em Marx, o ponto de partida do capital é o valor. A partir das mutações das formas do valor, o aspecto central a ser observado é a capacidade que o sistema tem de se auto-desenvolver, de se auto-valorizar. Se na circulação simples das mercadorias o objetivo era obter valor de uso, no ciclo do capital, ao contrário, a finalidade é de fazer circular o dinheiro como capital. A mutação e a valorização do valor incorporam então um estágio mais desenvolvido, mais avançado do sistema, alcançando a transição do dinheiro ao capital, ou como diz Marx (1948, p. 156), "a circulação do dinheiro como capital possui, ao contrário, seu objetivo nele mesmo; porque é nesse movimento sempre renovado que o valor continua a se valorizar. Então, o movimento do capital não tem limites" (NT). Como sabemos, essa transformação é objeto de análise do capítulo IV do Livro I de $O$ Capital.

Nesse sentido, é necessário propor invariavelmente novas rotações no ciclo do capital, fazendo completar, de maneira alternada, as etapas - de compra e venda - da equação simplificada do ciclo global (D - M - D'). Nesse caso, valor é valor em atividade, dinheiro em processo, e por via de consequência, capital. No ciclo do capital, mercadoria e dinheiro são formas de existência do capital, eles manifestam a composição do capital. O capital vai, então, representar um movimento contínuo de valorização do valor que se exprime pela exploração da força de trabalho, a

(6) Hobson (1983, p. 24), por exemplo, diz que "abstratamente, o dinheiro ou o controle do dinheiro, às vezes denominado crédito, é capital. Concretamente, o capital consiste em todas as formas de matéria negociável que incorporem trabalho". Já Schumpeter (1985, p. 125) afirma que "o capital não é outra coisa que a alavanca que permite ao empresário de submeter à sua dominação os bens concretos que ele tem necessidade, nada mais que um meio de dispor de bens para novos fins, ou que um meio de imprimir à produção sua nova direção (...) a função do capital é de dar ao empresário os bens que devam ser empregados produtivamente, "trabalhados", podemos dizer. O capital é o meio de se procurar os bens. Ele está entre o empresário e o mundo dos bens como um terceiro agente necessário à produção numa economia de trocas. Ele faz a ponte entre os dois” (ibid, p. 126). Finalmente, Rosdolsky (2001) fez, no capítulo 11, um pequeno resumo dos conceitos mais utilizados sobre o capital. 
única mercadoria capaz de realizar a transformação do dinheiro em capital. Assim, Capital é valor que se valoriza constantemente através da produção da mais-valia; ele é o valor inscrito numa etapa mais desenvolvida da sociedade capitalista, ele constitui finalmente a afirmação e consolidação do capitalismo como sistema econômico ${ }^{7}$.

A mercadoria, o dinheiro e o capital constituem uma força hegemônica. $\mathrm{O}$ território da mercadoria e do capital é o espaço onde reina a lei do valor, representando a exploração imposta aos trabalhadores. A sociedade é submetida a essa correlação de forças. Finalmente, a transformação do dinheiro em capital produz os seguintes resultados: " $1{ }^{\circ}$ que o produto pertence ao capitalista e não ao trabalhador; $2^{\circ}$ que o valor desse produto, além do valor do capital adiantado, inclui uma mais-valia, a qual custou trabalho ao trabalhador, mas nada ao capitalista, e que todavia torna-se propriedade legítima deste; $3^{\circ}$ que o trabalhador continuou a manter sua força de trabalho e pode vendê-la de novo, caso encontre comprador" (Marx, 1984a, p. 167).

Nós constatamos certas diferenças entre "ser valor" e "viver como capital". O capital, enquanto valor que se valoriza, que circula, a partir de metamorfoses, sempre procura a auto-valorização. Evidentemente que o sujeito, o agente responsável pelas transformações é o valor-trabalho. A diferença é que agora o capital adquire a característica do movimento, a possibilidade de evoluir e crescer. "Aqueles que consideram a autonomização do valor como mera abstração esquecem que o movimento do capital global é essa abstração in actu. $\mathrm{O}$ valor percorre aqui diferentes formas, diferentes movimentos, nos quais se mantém e, ao mesmo tempo, se valoriza, aumenta" (Marx, 1984b, p. 78).

Finalmente, encontramos nesse momento os princípios nos quais o valortrabalho assume sua forma dinheiro ou mercadoria, constituindo as etapas da circulação e da produção do capital. Essas etapas nos reenviam à formação do capital industrial e às formas funcionais autonomizadas do capital.

\section{As formas funcionais do capital}

No Livro II de $O$ Capital, Marx desenvolve, na primeira seção (As metamorfoses do capital e seu ciclo), suas idéias sobre a rotação e circulação do capital $^{8}$. Nessa mesma, o circuito é apresentado, em seu início, em partes, como se ele estivesse isolado, mas com o objetivo de estabelecer suas interconexões. Sua

(7) Uma leitura mais detalhada sobre esta temática pode ser encontrada em Carcanholo (2011).

(8) Ribeiro (2009) nos apresenta uma boa síntese e análise dos principais assuntos tratados por Marx no Livro II, livro esse que, segundo o primeiro autor, "tem sido pouco estudado e os resumos existentes deixam muito a desejar" (ibid, p. 7). 
intenção, com a rotação global do capital, era de inserir a totalidade do movimento do valor. Para compreender esse processo, é necessário partir da idéia lançada por Marx das formas funcionais do capital industrial, representadas abaixo:

Figura 1

O capital industrial e suas formas funcionais

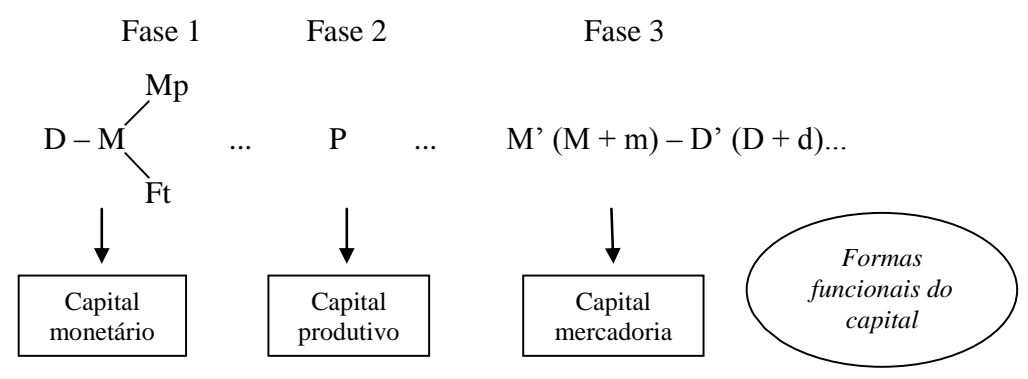

Onde: i) os três pontos ... indicam que a circulação do capital é interrompida mas que seu processo cíclico continua já que ela passa de uma esfera a outra; ii) $\mathrm{D}$, dinheiro; iii) $\mathrm{M}$, mercadoria; iv) $\mathrm{Mp}$, meios de produção; v) $\mathrm{Ft}$, força de trabalho; vi) P, produção; vii) M', capital mercadoria; viii) e D', dinheiro valorizado.

O capital aparece aqui formando três etapas sucessivas que estão em transformação e em conexão. As fases 1 e 3 referem-se à circulação das mercadorias e são chamadas de capital monetário (ou capital dinheiro) e capital mercadoria, respectivamente; a fase 2 é o momento da produção, onde o valor se reproduzirá a partir da mercadoria força de trabalho, é o capital produtivo. As funções de cada fase do ciclo são diferentes mas, em todas elas, o objetivo principal é de se valorizar. No estágio final, o movimento do ciclo recomeça, por hipótese, retornando ao seu ponto de partida. Assim,

O capital que no transcurso de seu ciclo global adota e volta a abandonar essas formas, e em cada uma cumpre a função que lhe corresponde, é o capital industrial. Capital monetário, capital-mercadoria, capital-produtivo não designam aqui tipos autônomos de capital, cujas funções constituam o conteúdo de ramos de negócios igualmente autônomos e mutuamente separados. Designam aqui apenas formas funcionais específicas do capital industrial, que assume todas as três, uma após a outra (Marx, 1984b, p. 41).

Na primeira fase de valorização, o dinheiro aparece como dinheiro que compra mercadorias na esfera da circulação, como a força de trabalho e os meios de produção adquiridos no mercado capitalista, para serem utilizadas na produção. Em D - M (Ft + Mp) a circulação do dinheiro exerce a função do capital monetário ao ser converter em Ft e Mp - já demonstrando as relações de classe no capitalismo 
-, o que permite a realização da massa de trabalho que será utilizada na etapa seguinte para produzir novas mercadorias. Nesse estágio, percebemos que o ponto de partida do ciclo capitalista é o dinheiro, já nos sugerindo a importância dos aspectos monetários na teoria Marxista. O resultado da primeira etapa do ciclo nos dá a possibilidade de começar a fase posterior; nesse caso, é a transformação do capital monetário em capital produtivo.

$\mathrm{Na}$ fase do capital produtivo, serão utilizadas as mercadorias adquiridas anteriormente, em que o valor avançado sob a forma monetária se transforma em capital, reforçando a generalização da classe trabalhadora assalariada e transformando a produção de mercadorias em produção capitalista de mercadorias. Aqui, as relações de classe tornam-se mais visíveis, a luta de classes idem. Essas relações produtivas, nas quais o capital está pressuposto como valor que se valoriza, guardam seu valor graças às trocas com o trabalho produtivo e cresce reproduzindo a mais-valia, aparecendo inteiramente dependente da relação entre capital e trabalho assalariado (Marx, 1980, p. 343). Os capitalistas ficarão com a mais-valia e aos trabalhadores resta o salário para reproduzir sua própria força de trabalho, desenvolvendo o ciclo da seguinte forma:

$$
\text { (1) } \mathrm{P} \ldots \mathrm{M}^{\prime}-\mathrm{D}^{\prime}-\mathrm{M}(\mathrm{Ft}+\mathrm{Mp}) \ldots \mathrm{P}^{\prime}
$$

Por fim, na terceira etapa do ciclo - a última fase de valorização que continua no ciclo global sob a base da equação (2) M' - D' - M' (Ft + Mp) ... P... M' ' -, M torna-se capital mercadoria, uma forma funcional de valorização do capital que retorna à circulação passando da forma mercadoria à forma dinheiro, uma verdadeira metamorfose, percorrendo, ao ser vendida no mercado, o circuito final M - D. O capital monetário inicial aplicado cresce, exterioriza o valor-capital valorizado, objetivo da circulação total do capital: D - D'. Aqui, diferente das fases anteriores, a valorização está ligada diretamente à venda a partir da transformação em D'. Nesse caso, não é demais afirmar, em primeiro lugar, que a retransformação do capital monetário inicial é uma função do capital mercadoria; segundo, que o valor de uso das mercadorias é importante para concluir o ciclo de rotação do capital e, finalmente, que o capital mercadoria permite a transformação da maisvalia que passa da forma mercadoria à forma dinheiro. O dinheiro valorizado (D') retornará, por hipótese, à etapa 1 do capital monetário mas agora sob a forma de capital, diferente de D, que circula como dinheiro: D' e M' são o valor-capital valorizado ${ }^{9}$. O ciclo pode recomeçar ${ }^{10}$.

(9) De fato, D' e M' representam a mesma coisa: ambos expressam o objetivo do capital monetário, mas sob as formas diferentes do capital: um sob a forma dinheiro, outro sob a forma mercadoria, respectivamente.

(10) Nesse momento, por hipótese, não há interrupções em alguma fase do ciclo, que caracterizariam as crises capitalistas. 
Apesar de Marx ter apresentado as formas funcionais do capital industrial de maneira separada em três etapas, elas representam em conjunto o ciclo de valorização do capital. A produção capitalista exige uma constante alternância entre as fases de produção e de circulação, formando uma unidade que começa e recomeça de maneira desordenada.

\section{A autonomização das formas funcionais do capital}

Partindo das indicações anteriores, podemos avançar na discussão. Se cada fase do ciclo do capital industrial representa funções específicas - a de capital monetário, a de capital produtivo ou a de capital mercadoria -, elas podem então ser controladas por um só capitalista ou uma empresa individual. No lugar de um só capitalista ocupando as três funções, prestamista de dinheiro (etapa 1), produtor (etapa 2) e vendedor (etapa 3), como implícito anteriormente, nós teremos cada capitalista ou cada empresa atuando sobre cada etapa particular, estabelecendo um processo de divisão social das funções. Concretiza-se, então, a autonomização das formas funcionais do capital em que cada um dos capitalistas especializa-se em uma função, aproximando-se da realidade e da complexidade do mercado capitalista.

Por consequência, com essa autonomização, o capital monetário inicial assume a forma de capital portador de juros ou capital a juros, em que as pessoas e as instituições vão tomar para si a função de prestamista (mutuante) de dinheiro. Por outro lado, o capital produtivo simboliza as modificações na esfera da produção e o capital mercadoria se autonomiza em duas partes: o capital de comércio de mercadorias e o capital de comércio de dinheiro. Essa divisão das funções provoca também a redução do tempo de trabalho e, como consequência, a diminuição do tempo de circulação do capital. Assim, a especialização social aumenta a rotação do capital permitindo o crescimento da mais-valia gerada no sistema.

No capital mercadoria, a primeira forma do capital comercial, o capital de comércio de mercadorias, reproduz, de certa forma, a especialização de uma etapa do capitalismo no ciclo global. Ela representa o capital monetário que permite uma circulação mais rápida das mercadorias, amplificando a rotação do capital. De fato, ela torna-se "o capital mercadoria do produtor" que vai emprestar o capital monetário, substituindo a figura do capitalista industrial. Aqui, estabelece-se uma diferença fundamental com os capitalistas industriais: agora, as operações de compra e venda serão executadas por uma categoria particular de capitalistas: os comerciantes. Com eles, constitui-se a autonomia dos investimentos particulares no ciclo do capital, eles executam a função de intermediários num comércio em que 
são possuidores de dinheiro, mediando as transações comerciais. O comerciante adianta "capital monetário que só se valoriza como capital, só funciona como capital, ao se ocupar exclusivamente em mediar a metamorfose do capitalmercadoria, sua função como capital-mercadoria, isto é, sua transformação em dinheiro, e ele o faz mediante constante compra e venda de mercadorias (...). Por meio dessa função ele transforma seu dinheiro em capital monetário (...) transforma o capital-mercadoria em capital de comércio de mercadorias" (Marx, 1984c, p. 207-208).

Naturalmente, os comerciantes, enquanto capitalistas, não produzem mercadorias, eles agem exclusivamente na esfera da circulação, não criando conseqüentemente valor. Mas a mais-valia contida nas mercadorias se expressará numa taxa de lucro que será em parte absorvida pelos mesmos quando os produtos forem vendidos no mercado. A autonomia do capital de comércio de mercadoria está na capacidade que ele tem de constituir um mercado particular, separado, em princípio, do capital produtivo. De fato, quando uma forma do capital funcional se autonomiza, ela se converte em capital autônomo, que funcionará como mediador no processo de circulação do capital e o capitalista atuante no capital produtivo não terá necessidade de esperar a venda de seu produto para continuar a produção. Daí vem sua autonomia, trazendo vantagens para o sistema, já que há uma especialização das atividades, além do que a rotação do ciclo do capital será mais rápida - contribuindo para a metamorfose das etapas do ciclo global -, ampliando o mercado e a divisão do trabalho. É verdade também, como veremos em breve, que a tendência natural do sistema é a de diminuir o espaço do capital comercial de mercadorias a partir do desenvolvimento do sistema de crédito já que, a partir desse último, é possível comprar mercadorias sem utilizar diretamente o dinheiro.

A substantivação do valor continua seu percurso se engajando também no movimento autonomizado sob a forma de capital de comércio de dinheiro ${ }^{11}$. Com ela, o sistema de crédito se intensifica assumindo a forma do capital portador de juros e do capital fictício. A Figura 2 seguinte nos dá uma visualização do percurso do capital.

(11) Os problemas de tradução envolvendo categorias como capital comercial/capital mercantil, capital de comércio de dinheiro/capital financeiro, por exemplo, não podem ser menosprezados. Eles provocam mudanças significativas na compreensão e interpretação dos fenômenos. Para nós, por exemplo, concordando com Harvey (1990), Klagsbrunn (1992) e Germer (1995), não existe o conceito de capital financeiro em Marx. Conforme Klagsbrunn (1992, p. 603), "na edição de $O$ Capital da Editora Civilização Brasileira, essa função específica foi traduzida como "capital financeiro", expressão que pouco tem a ver com a original Geldhandlungskapital, tanto em termos literais quanto em conteúdo (...). Ao que tudo indica, a origem do erro está na tradução francesa da Editions Sociales, Paris, 1976, (tradução de Mm Cohen-Solal e M. Gilbert Badia), na qual o título do cap. 19, página 301, aparece como Le Capital Financier (Capital Marchant)", no lugar de Capital de Comércio de Dinheiro. 
Figura 2

A autonomização das formas funcionais do capital e a desmaterialização do dinheiro

Fase $1 \quad$ Fase $2 \quad$ Fase 3

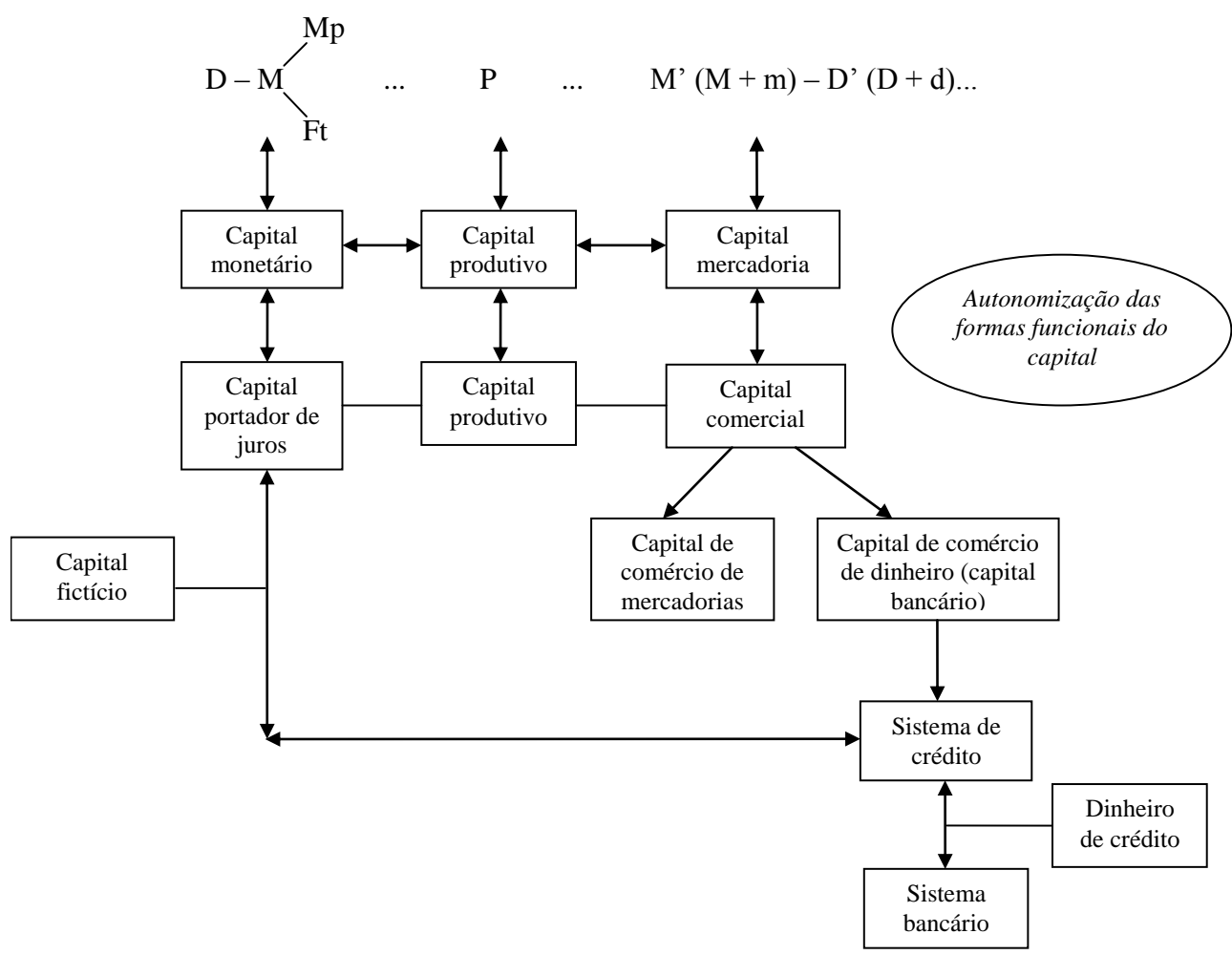

Onde: D, dinheiro; M, mercadoria; Mp, meios de produção; Ft, força de trabalho; P, produção, D', dinheiro valorizado; M', capital mercadoria.

Fonte: Elaboração do autor.

Com as transações de compra e venda entre comerciantes e consumidores, a circulação do capital aumentará e o capitalista proporcionará dinheiro a várias pessoas, ao mesmo tempo em que ele recebe os pagamentos de um grande número de outros indivíduos. Neste momento, surgem as operações técnicas de pagamentos de mercadorias, a necessidade de quadros de agentes contábeis, de cálculos de compensação, etc. Organiza-se, então, uma nova divisão do trabalho incluindo novos agentes de operação e novas instituições como as agências contábeis e os bancos. "As diferentes operações, de cuja autonomização em atividades específicas se origina o comércio de dinheiro, resultam das diferentes determinações do próprio dinheiro e de suas funções, que, portanto, também o capital na forma de capital monetário tem de realizar" (Marx, 1984c, p. 238).

O capital de comércio de dinheiro facilita, portanto, as operações de compensação pelos mecanismos contábeis, de operações de crédito e de débito, ele 
é um capital que tem por função executar o financiamento, ampliando inclusive o número de capitalistas na esfera financeira, conseqüência da autonomização das formas funcionais do capital. O pleno desenvolvimento do capital de comércio de dinheiro se efetua desde que se acrescente o empréstimo e o comércio a crédito.

Até esse momento, pressupõe-se que o comércio de dinheiro estava ainda em sua forma pura, a mais simples, quer dizer, separada do sistema de crédito. Marx estudava um momento da circulação das mercadorias, a circulação monetária. Apesar disso, podemos dizer que a massa do capital monetário, o capital de comércio de dinheiro, travestido agora pelos banqueiros e outras instituições financeiras, é o capital monetário em circulação dos comerciantes e industriais. Nós chegamos agora a outras categorias que são fundamentais para entender o desenvolvimento e as contradições do capitalismo contemporâneo: o dinheiro de crédito, o capital portador de juros e o capital fictício.

\section{A desmaterialização do dinheiro: o crédito, o capital portador de juros e o capital fictício}

Apresentaremos, agora, aquilo que consideramos ser as formas mais desenvolvidas do movimento de desmaterialização do dinheiro: o dinheiro de crédito (sistema de crédito, sistema bancário), o capital portador de juros e o capital fictício.

Nas pesquisas sobre o crédito em $O$ Capital, Marx pouco desenvolveu o estudo do capital fictício. Mesmo o capital portador de juros e o sistema de crédito não ocupam um espaço vasto em suas obras. As razões para isso já foram apontadas por Rosdolsky (2001), especialmente no capítulo 27. De questões de saúde do próprio autor até as dificuldades naturais de Engels em finalizar o Livro III de $O$ Capital, o fato é que a discussão sobre categorias como capital portador de juros e capital fictício está, a nosso ver, em construção, principalmente quando se trata de utilizá-las no estudo das transformações do capitalismo contemporâneo, com destaque especial para a manifestação de suas crises via movimentos especulativos financeiros.

De todas as formas, nós podemos afirmar que os elementos centrais que caracterizam os aspectos da especulação financeira atual estão presentes nas obras de Marx nos capítulos do Livro III de $O$ Capital e nos anexos das Teorias da maisvalia. No Livro III, onde se apresentam os elementos da aparência, aqueles contidos na "superfície da sociedade", Marx deixa claro que "trata-se muito mais de encontrar e expor as formas concretas que surgem do processo de movimento do capital considerado como um todo" (Marx, 1984c, p. 23). Em pleno século XIX, num processo de formação e transformação radical das esferas financeira e industrial do capitalismo, Marx já desenvolvia os instrumentos de análises que 
permitem revelar os “novos" mistérios do ciclo D - D', de valorização fictícia do capital.

A categoria do capital fictício se desenvolve de maneira paralela e em interconexão com o capital portador de juros, da mesma forma que acompanha a extensão do crédito na economia capitalista. O crédito, assim como o sistema de crédito, é o resultado e a condição de existência da produção capitalista e da reprodução de seu ciclo. Para Mandel (1962), o crédito "não é uma instituição natural, mas um produto de relações sociais determinadas" (NT), que aparece e se intensifica com o capitalismo, economizando o tempo de trabalho já que permite a continuidade do ciclo global de reprodução sem que seja necessário adiantar dinheiro para concluir as vendas finais para o consumo.

Em primeiro lugar, o crédito contribui para a autonomização do capital já que colabora para a divisão do trabalho, mas, principalmente, porque separa ainda mais a produção da circulação: é possível comprar sem vender; segundo, a mercadoria não será mais vendida pelo pagamento direto em espécie, mas a partir de um título que dá garantia de um pagamento futuro sob a forma, por exemplo, de títulos comerciais, formando uma compensação de dívidas e de obrigações sem a intervenção direta do dinheiro, aparecendo assim as primeiras formas do dinheiro de crédito propriamente dita. Dá-se, então, a substituição cada vez mais frequente do dinheiro pelo dinheiro de crédito - que se apresenta hoje sob formas diferenciadas como cheques bancários, títulos de crédito, bilhetes bancários e carta de crédito -, constituindo a base do sistema bancário e contribuindo para a reprodução do movimento do capital.

No Livro II de $O$ Capital, Marx defende que existem, depois do desenvolvimento completo do ciclo do capital, três formas características do movimento econômico da produção social: a economia natural, a economia monetária e a economia de crédito. "A assim chamada economia de crédito é, ela mesma, apenas uma forma da economia monetária (...) na produção capitalista desenvolvida, a economia monetária aparece apenas como base da economia creditícia. Assim, a economia monetária e a economia creditícia só correspondem a estágios diferentes de desenvolvimento da produção capitalista (...)" (Marx, 1984b, p. 85$)^{12}$.

Todo o processo caminha paralelamente ao sistema de crédito. Se o sistema monetário, que se encarna na circulação do dinheiro, se aproxima da circulação do

(12) Para Brunhoff (1976), existe, em Marx, uma "teoria monetária do crédito" que levaria seus escritos a serem considerados como uma "teoria do crédito". A "teoria monetária do crédito", segundo a autora, conduz a "uma concepção unitária do crédito, que engloba as estruturas financeiras (mercados e instituições de crédito), assim como sua função conjuntural, numa interpretação relativa às propriedades únicas da moeda e do capital monetário" (NT) (ibid, p. 108). A nosso ver, a interpretação da autora, se não for bem contextualizada, pode expressar uma visão unidimensional do crédito, deslocando-o completamente do sistema monetário. 
valor sob a forma simples, em que o dinheiro executa seja a função de meio de circulação, seja a de meio de pagamento, o sistema de crédito representa a circulação de valores já constituídos sob a forma de dinheiro (de crédito), apesar de Marx não ter aprofundado - como ele mesmo disse no capítulo "Crédito e capital fictício" - as análises sob o sistema de crédito, afirmando nas Teorias... que "o sistema de crédito é sua própria criação, é mesmo uma forma do capital industrial que inicia com a manufatura e continua a se desenvolver com a grande indústria. Na origem, o sistema de crédito é uma forma polêmica contra os usurários à moda antiga" (NT) (Marx, 1976,p. 554-555).

Dessa forma, o capital de comércio de mercadorias e o capital de comércio de dinheiro se concentram na estrutura do sistema bancário - que os administrará e executará as funções de gestão do capital monetário, controlando o dinheiro em espécie (depósitos), os títulos (comerciais, públicos, ações etc), constituindo o capital bancário - e compreendem o sistema de crédito; evidentemente, toda essa evolução contribuiu para o crescimento da esfera financeira do capital e, consequentemente, para aumentar em certo grau o "descolamento" entre as chamadas esferas real, financeira e especulativa.

Em função dessas características, as instituições bancárias têm o poder de criar dinheiro de crédito, já que reagrupam e centralizam o capital monetário, disponibilizando-o ao público sob diversas formas. Os ativos bancários são "ilusórios", sem alguma ligação com a poupança real e sem garantia de cobertura bancária concernente a todos os empréstimos. $\mathrm{Na}$ verdade, "a maior parte do capital bancário é, portanto, puramente fictícia e consiste em títulos de dívidas (letras de câmbio), títulos de dívida pública, (que representam capital passado) e ações (direitos sobre rendimento futuro) (...) esse capital fictício do banqueiro, em grande parte, não representa seu próprio capital, mas o do público, que o deposita com ele, com ou sem juros" (Marx, 1985, p. 13). Ou seja, o sistema bancário foi uma via decisiva para a formação e crescimento do capital portador de juros e do capital fictício, que analisaremos agora.

\section{O capital portador de juros}

O ponto de partida do capital portador de juros é o empréstimo de capital monetário $\mathrm{D}_{1 \mathrm{~A}}$ a um capitalista $\mathrm{B}$ que, por hipótese, utilizará esses recursos como capital monetário $\mathrm{D}_{1 \mathrm{~B}}$ no ciclo do capital, em atividades industriais ou comerciais, como pode ser observado na equação seguinte:

$$
\text { (3) } \mathrm{D}_{1 \mathrm{~A}}(\mathrm{~A})-\mathrm{D}_{1 \mathrm{~B}}(\mathrm{~B}) \ldots \mathrm{M} \ldots \mathrm{D}_{2 \mathrm{~A}}-\mathrm{D}_{2 \mathrm{~B}}(\Delta+\Delta \mathrm{D}) \text {, onde: }
$$

$\mathrm{A}$, prestamista (mutuante); $\mathrm{B}$, mutuário; $\mathrm{D}_{1 \mathrm{~A}}$, capital monetário do prestamista; $\mathrm{D}_{1 \mathrm{~B}}$, capital monetário do mutuário; $\mathrm{M}$, produção de mercadorias; $\mathrm{D}_{2 \mathrm{~A}} \mathrm{e} \mathrm{D}_{2 \mathrm{~B}}$, capital monetário valorizado; $\Delta+\Delta \mathrm{D}$, mais-valia. 
$\mathrm{O}$ dinheiro percorre a primeira etapa da equação $\mathrm{D}_{1 \mathrm{~A}}-\mathrm{D}_{1 \mathrm{~B}}$ até sua entrada no ciclo do capital produtivo $\mathrm{M}$ para a produção da mercadoria, mas agora com uma diferença fundamental em relação às análises precedentes do ciclo global: no capital portador de juros, o capitalista A não aplica diretamente seu dinheiro na produção; ao contrário, ele fornece ao capitalista B (em função) a capacidade de utilização de seu capital monetário, oferecendo o valor de uso de seu dinheiro para transformá-lo em capital. Naturalmente, exigirá em contrapartida uma parte do excedente $(\Delta+\Delta \mathrm{D})$ gerado na produção.

A fração destinada aos capitalistas prestamistas será os juros que "não é senão uma parte do lucro do capitalista industrial paga ao proprietário do capital" (Marx, 1976, p. 556), uma parte da mais-valia destinada ao capitalista A, a "recompensa" que o mesmo recebe, dissimulando ainda mais a relação de exploração na sociedade capitalista. Nesse caso, a especialização capitalista perpetua a autonomização das formas funcionais do capital pelo desenvolvimento da divisão das funções entre capitalistas monetários e produtivos, efetuando a conversão de uma parte do lucro em juros. Para o capitalista B, o "ganho do empresário"; para o A, a acumulação sob a forma de juros.

O capital monetário, logo que se transforma em capital portador de juros, se converte em mercadorias necessárias ao funcionamento da estrutura produtiva do capital, gerando um excedente que, como sabemos, não retorna aos trabalhadores, já que a mais-valia produzida é distribuída em frações representadas sob a forma de lucro, juros e renda da terra. Nesse momento, o capital portador de juros se legitima no ciclo capitalista, o que o identifica diretamente a uma atividade produtora de valor: "Uma vez que a produção capitalista esteja desenvolvida na amplitude de suas formas, uma vez que ela é o modo de produção dominante, o capital portador de juros é dominado pelo capital industrial e o capital comercial não é senão um aspecto do capital industrial, derivado do processo de circulação. Mas como formas autônomas é necessário que todas as duas sejam destruídas e submissas ao capital industrial” (NT) (Marx, 1976, p. 554).

O capital portador de juros fica atrelado e dominado pelo capital industrial, num momento histórico do capitalismo onde se observava o processo da revolução industrial, dissimulando ainda mais a relação capital-trabalho já que ele "(...) não se opõe, enquanto tal, ao trabalho assalariado, mas ao capital em função" (Marx, 1978, p. 44). Ou seja, a sua remuneração sob a forma juros aparece como parte não-integrante do processo produtivo, sob a tutela de uma relação reificada, uma relação fetichizada do capital, onde a apropriação do capital se dá aparentemente sem trabalho, separada de todas as conexões com o excedente do trabalho ${ }^{13}$.

(13) Ao contrário, “o juro em si expressa justamente a existência das condições de trabalho como capital, em sua antítese social ao trabalho e em sua transformação em poderes pessoais, em face do trabalho e sobre o trabalho. Ele representa a mera propriedade de capital como meio de apropriar-se de produtos do trabalho alheio" (Marx, 1984c, p. 285). 
Nesse momento, o capital portador de juros aparece como a forma mais perfeita do fetiche, já que a mediação entre o monetário, expresso pelo capital monetário, e o real, pela geração de valor na produção, fica mascarada, aparentemente sem representatividade. Com o sistema de crédito, o capital portador de juros adquire a importante função de prestamista, necessária à reprodução do ciclo global capitalista, particularmente do financiamento do capital produtivo. A autonomização do capital monetário, sob a forma do capital portador de juros, aumenta o espaço do sistema bancário transformando-o profundamente, implicando numa certa superioridade do banqueiro, como assinala Hilferding (1985), já que o crédito bancário se impõe e controla as relações de mercado ${ }^{14}$.

Por fim, os "mistérios" das relações entre mercadoria e dinheiro continuam através da forma capital portador de juros, mas a autonomização das formas funcionais do capital e a desmaterialização do dinheiro atinge níveis de abstração e complexidade ainda mais elevados. É o aparecimento do capital fictício, categoria central na análise do capitalismo contemporâneo e de suas crises.

\section{O capital fictício}

Apesar da intitulação do Capítulo XXV do Livro terceiro de O Capital - "O crédito e o capital fictício" - é sobretudo no Capítulo XXIX - "Composição do capital bancário" - e no Capítulo XXX - "Capital monetário e capital real" - que, a nosso ver, Marx faz uma exposição mais direta e mais precisa do capital fictício.

Mesmo se Marx não pôde completar todas as ideias sobre o capital fictício em suas obras, mesmo porque o período histórico vivido pelo autor ainda era de um capitalismo em desenvolvimento, ele nos deixou elementos fundamentais que permitem compreender os movimentos fictícios do capital e suas características no seio da acumulação capitalista mundial. O fato é que a autonomização do capital no esquema de reprodução financeira, baseada no desenvolvimento do sistema de crédito (dinheiro de crédito), ampliou-se e atingiu um grau ainda mais sofisticado que o do capital portador de juros. Supondo mesmo que a forma do capital monetário (portador de juros) "seja meramente a de dinheiro real, ouro ou prata, da mercadoria cuja matéria serve de medida dos valores, ainda assim uma grande parte desse capital monetário é sempre necessariamente apenas fictícia (...)" (Marx, 1985, p. 43).

(14) Analisando historicamente o capital monopolista e o império da alta finança nos Estados-Unidos na primeira metade do século XX, Perlo (1974) sublinha o controle hegemônico dos bancos e instituições financeiras e reafirma a necessidade de apreender suas estratégias para penetrar no centro das decisões políticas. Baseando-se nas idéias de Hilferding e Lênin, o autor afirma que "não se trata de uma conquista da indústria pelos grupos financeiros, ou vice-versa, mas da fusão de uma e dos outros para formar uma nova oligarquia financeira (...) essa oligarquia não é de nenhuma forma unificada" (ibid, p. 59). 
Marx sugere que a utilização do dinheiro como capital monetário no sistema de crédito, logo que ele é transformado em capital portador de juros, existirá como um direito de uma renda futura antecipada sob a forma de títulos e "a massa de títulos representa um capital fictício que, sob a aparência de uma fração do capital total, esconde seu verdadeiro caráter: esse de ser um simples título de renda, dando direito à participação na divisão da mais-valia social” (NT) (Mandel, 1962, p. 99). Como vimos anteriormente, a acumulação de direitos sobre a produção futura fica ligada, sob a forma de capital portador de juros, a uma acumulação real que provém da transformação do capital monetário na esfera de valorização do capital. No entanto, "com o desenvolvimento do capital portador de juros e do sistema de crédito, todo capital parece duplicar e às vezes triplicar pelo modo diverso em que o mesmo capital ou simplesmente o mesmo título de dívida aparece, em diferentes mãos, sob diversas formas. A maior parte desse "capital monetário" é puramente fictícia" (Marx, 1985, p. 14). De fato, "nesse sistema de crédito tudo se duplica e triplica e se transforma em mera quimera..." (ibid, p. 15), quer dizer, forma fantasmagórica, ilusória, fictícia.

Para Harvey (1996, p. 171),

este capital fictício é definido como capital que tem valor monetário nominal e existência como papel, mas que, num dado momento do tempo, não tem lastro em termos de atividade produtiva real ou de ativos físicos. O capital fictício é convertido em capital real na medida em que são feitos investimentos que levem a um aumento apropriado em ativos úteis (por exemplo, instalações e equipamentos que possam ter emprego lucrativo) ou mercadorias úteis (bens e serviços que possam ser vendidos com lucro).

Apesar da correta caracterização do capital fictício, não concordamos em uma coisa com Harvey - e também com outros autores de grande expressão que têm uma perspectiva similar a dele ${ }^{15}$ : nós cremos que a partir do momento em que o dinheiro de crédito entra no ciclo do capital como capital monetário implicado numa atividade produtiva, real, ele será capital portador de juros, e não capital fictício. Esse possível mal-entendido vem do fato de que o capital portador de juros, que financia a produção e circulação, e o capital fictício são categorias diversas, apesar do fato de que o segundo nasce como consequência da existência generalizada do primeiro. No capital fictício não há nenhuma substância real e ele não contribui em nada à produção ou à circulação da riqueza, ao menos no sentido de que não financia nem o capital produtivo, nem o capital comercial ${ }^{16}$.

(15) Como Katz (2002), Corazza (1999), dentre inúmeros outros.

(16) O capital fictício gerado pode ser o "reflexo em um espelho do capital a juros". Nesse caso, ele assume uma forma intitulada por nós de capital fictício de tipo 1, que se "espelha" sob a forma de uma acumulação real, portanto, produtiva. Já o capital fictício de tipo 2 aparece meramente como resultado da especulação financeira, não tendo nenhuma substância real por trás, onde possa se "espelhar". Sobre essas duas categorias, consultar Carcanholo e Sabadini (2009). 
Além do mais, o capital fictício é essa forma de capital cujo valor deriva de um fluxo de renda correspondente a um capital já realizado, sobre o qual se aplica uma taxa de juros, de forma que o proprietário do capital começa a ganhar uma remuneração sem contrapartida em capital produtivo (Carcanholo e Sabadini, 2009). Dessa forma, o desenvolvimento do capital fictício - caracterizado por diversos instrumentos financeiros como as ações, títulos públicos... - dissimula ainda mais as conexões com o processo real de valorização do capital, consolidando a imagem de que ele se valoriza por si mesmo, nas transações de compra e venda especulativas.

Por isso, se Marx falava do capital portador de juros como uma forma mistificada, com o capital fictício esta conformação assume um aspecto ainda mais complexo e desmaterializado, situando-se num nível ainda mais elevado do fetiche das mercadorias. Então, o capital portador de juros não pode ser confundido com o capital fictício que ele mesmo produz. O primeiro é real - exigindo um pagamento por seus empréstimos sob a forma de juros e lucros -, e corresponde a uma riqueza real que foi produzida sob a forma de excedente, e o segundo é submetido à dialética real-fictícia, já que o indivíduo recebe um lucro (fictício) por suas transações financeiras, portanto existe concretizado em algo real, mas que, enquanto coletividade - a qual pertence o conjunto dos capitalistas -, não produz substância associada ao valor-trabalho, portanto, fictício ${ }^{17}$.

É verdade, como afirma Corazza (1999), que nos movimentos financeiros do capitalismo contemporâneo o capital portador de juros tende a ser confundido com o capital fictício, já que seus movimentos estão cada vez mais entrelaçados. Mas, essa complexidade a nosso ver não justifica afirmações de que o capital fictício possa financiar a acumulação real, pois, como indicamos, o capital portador de juros e o fictício são categorias diferentes. É verdade também que um titular de uma massa de capital fictício pode trocar, no mercado, seu capital por outra forma que vise financiar a produção ou circulação do capital. Porém, se assim o faz, o capital fictício muda de mãos, de forma que o valor total na economia não seja alterado (Carcanholo; Sabadini, 2009, p. 47).

O mais importante é que acreditamos que com o capital fictício a forma de autonomização do valor é mais reificada, mais mistificada vis-à-vis o capital portador de juros, tornando assim mais elevado o caráter fetichista das mercadorias, do dinheiro, e como consequência do capital. A especulação ganha contornos ainda mais definidos e intensos; como afirmou Hilferding (1985, p. 205):

(17) "Tudo isso depois que o montante emprestado não existe mais e não produz mais novo valor na produção, que seria a base para tais rendimentos. Trata-se então de um caráter fictício já que existe sem base em valor criado, sem lastro em valor, sem relação com o capital produtivo" (Mollo, 1989, p. 55). 
“é a aparição desse mercado do capital fictício que dá à especulação a possibilidade de se exercer" 18 .

Se o capital fictício não agrega valor, ele exige remuneração. Por um lado, uma parte dessa vem do pagamento dos juros; por outro, vem das oscilações especulativas dos preços dos ativos, que chamamos de lucros fictícios ${ }^{19}$. Assim, num primeiro momento, essas remunerações são meras transferências de valorexcedente que são produzidos por outros capitais. Pelo fato de que o capital bancário é composto de dinheiro, de títulos, de ações e de depósitos e bilhetes bancários, todos esses ativos dão direito a um ganho futuro que se multiplica através de diversas transações fictícias, operadas num "mundo de papéis", usando a expressão de Marx, e que estão presentes na categoria do capital fictício, chamada por Marx de capitalização.

A dívida pública e as ações constituem um dos principais representantes do capital fictício. Por um lado, a instrumentalização do capital fictício pelo Estado, a partir da dívida pública, funciona como um mecanismo de acumulação e de centralização do capital, transferindo uma parte da mais-valia para a esfera financeira. Por outro, a venda das ações nas bolsas de valores que, apesar de apresentar um lado real via emissões primárias, “é em parte especulativo, pois não é determinado apenas pela receita real [da empresa], mas também pela esperada, calculada por antecipação (...) seu valor sempre é apenas o rendimento capitalizado, isto é, o rendimento calculado sobre um capital ilusório, com base na taxa de juros vigente" (Marx, 1985, p. 12).

Mas, como duplicatas que são, em si mesmas, negociáveis como mercadorias e, por isso, circulam como valores-capitais, elas são ilusórias e seu montante de valor pode cair ou subir de modo inteiramente independente do movimento de valor do capital real, sobre o qual são títulos [detentores de um direito de propriedade] (...) ganhar e perder pelas flutuações de preços desses títulos de propriedade (...) Essa espécie de riqueza monetária imaginária não apenas constitui uma parte muito considerável de riqueza monetária dos particulares, mas também do capital dos banqueiros, conforme já mencionamos (Marx, 1985, p. 20).

(18) E é neste sentido que Braga (2000, p. 222-223) afirma que a novidade no capitalismo contemporâneo encontra-se no que chama de Processo de Capitalização Financeira que a partir dos capitais centralizados "impulsionam nos mercados monetário, cambial, acionário, creditício, imobiliário, de capitais e de commodities uma massa de riqueza financeira". Esta capitalização é "formada por juros, dividendos, amortizações de empréstimos, rendimentos provenientes das diferentes operações com ativos financeiros (inclusive títulos da dívida pública) e com moedas conversíveis, constituindo uma espécie de "estrato superior" de riqueza", sendo que parte dela tem origem na esfera produtiva, estando "ancorada nos lucros operacionais ou até mesmo nas poupanças das famílias originadas dos rendimentos do trabalho e hoje operadas basicamente pelos investidores institucionais", e outra parte "é riqueza fictícia, correspondendo a parte das operações especulativas que geram ganhos de capital (nas bolsas), de arbitragem (câmbio e juros) e aqueles decorrentes de valorizações patrimoniais com ativos mobiliários e imobiliários em geral".

(19) Para uma discussão sobre os lucros fictícios, ver Carcanholo e Sabadini (2009). 
A bolsa de valores torna-se, então, lócus do capital fictício. A questão é que o capital fictício tende a ultrapassar seus limites, seja pelo aumento significativo da dívida pública e/ou pelos movimentos especulativos nas bolsas de valores, por exemplo. Se o capital fictício funciona, por um lado, como uma contra-tendência à queda na taxa de lucro, por outro carrega o germe de sua própria ruptura e instabilidade, muitas vezes representada por crises, como as que presenciamos no capitalismo contemporâneo. Neste caso, ele expressa, ao mesmo tempo, sua natureza dialética de solução e problema para o capitalismo. A própria exigência de alta remuneração provoca várias consequências no âmbito macroeconômico, como a redução dos gastos sociais e a transferência de riqueza para o pagamento dos serviços da dívida pública, além de efeitos diretos sobre a exploração da força de trabalho no interior das grandes unidades industriais, pressionadas para aumentar a produção de mais-valia que será repartida com a esfera financeira do capital sob a forma do pagamento de dividendos ${ }^{20}$.

Finalmente, o fato de o capital fictício ter, diferentemente do capital portador de juros, certa autonomia em relação à esfera produtiva não significa dizer que ele não interfere na dinâmica da acumulação capitalista e, portanto, no cotidiano da sociedade. Ao contrário. As crises capitalistas que se manifestam na esfera financeira, por exemplo, recorrentes nas últimas décadas e fortemente caracterizadas pelos movimentos especulativos, exerceram influência direta e intensa sobre todos os setores da atividade econômica (comércio, indústria, serviços, finanças...). Assim, o capital fictício é funcional para a reprodução do capital, introduzindo a especulação que é real. $\mathrm{O}$ fato é que a configuração histórica inicial do capitalismo, onde o capital portador de juros atuava como dominante, deu lugar a um espaço onde a esfera fictícia do capital assumiu uma posição relevante, quiçá central, ao menos nas últimas décadas do século XX e início do século $\mathrm{XXI}^{21}$.

\section{À guisa de conclusão}

O crescimento do capital fictício, baseado em diversos instrumentos financeiros (ações, títulos...), desenvolveu ainda mais a relação fetichista das mercadorias. Quanto mais a substantivação do valor e a autonomização do capital

(20) Para uma análise sobre o capital fictício e seus efeitos sobre a macroeconomia e sobre o mundo do trabalho no Brasil, ver Sabadini (2008).

(21) Essa observação não significa dizer, naturalmente, que o capital produtivo e a classe ligada à esfera produtiva fracassaram, por um lado, e os capitalistas representantes da esfera financeira do capital são, por outro lado, os únicos ganhadores. Muito menos significa dizer que o capital produtivo está, no capitalismo contemporâneo, isolado das outras frações do capital, dando a impressão de um "fatalismo financeirizado". De fato, a produção prossegue criando excedente, o trabalho continua central, a teoria do valor-trabalho se radicaliza e os interesses do capital continuam os mesmos... 
se ampliam, mais as conexões com o trabalho se tornam enigmáticas. Ao mesmo tempo, dialeticamente, reafirma-se o trabalho como criador de valor.

O capital fictício ocupou um espaço fundamental na reprodução do capitalismo contemporâneo, a fim de aumentar e acelerar o processo de rotação do capital para contrariar a queda na taxa de lucro industrial. Ao mesmo tempo, acentuou o caráter contraditório, e, portanto, dialético, entre a expansão real e financeira do capital. A capitalização, representada pelas rendas obtidas a partir dos títulos financeiros e dos direitos de propriedade (ações) sobre as rendas futuras, ultrapassa cada vez mais os limites materiais da produção capitalista. A tendência, então, é a de que o dinheiro de crédito, fortemente desmaterializado, provoque crises financeiras profundas e fortes movimentos especulativos nos centros financeiros, como as que conhecemos nas últimas décadas do século XX e início do século XXI.

Ao mesmo tempo, com o processo de autonomização das formas funcionais do capital, o circuito financeiro do capital, sob a égide do capital fictício, cresceu e exerceu forte pressão sobre o capital produtivo, aumentando a lógica especulativa do mercado. É verdade, como afirmamos anteriormente, que essa dinâmica da acumulação que caracteriza o capitalismo contemporâneo não pode ser tratada sob a forma de um "fatalismo financeiro", como se fosse regida exclusivamente por transações financeiras, cuja maior parte é fictícia.

Apesar de falarmos em "autonomia relativa" do circuito financeiro do capital - num dado momento histórico do capitalismo em que a especulação financeira teve espaço predominante -, mostramos também que a teoria do valor continua no centro das interpretações, em que o trabalho, cada vez mais explorado e intensificado, é a fonte central de geração de valor. Então, se há, de um lado, um movimento especulativo aparentemente separado da esfera produtiva, de outro, os movimentos dos circuitos financeiros e produtivos do capital guardam suas relações dialéticas de independência e complementaridade.

Por fim, nosso principal propósito aqui foi o de mostrar que o processo teórico de evolução das formas autônomas do capital desenvolvido por Marx, caracterizado principalmente pelo capital fictício, é uma poderosa ferramenta para compreender as mutações verificadas no capitalismo contemporâneo, servindo também de instrumental para a explicação das crises capitalistas atuais. Tais sugestões comprovam, ao contrário do que se afirma comumente, o grau de profundidade e atualidade da teoria econômica Marxista para explicar o funcionamento do capitalismo contemporâneo. 


\section{Referências bibliográficas}

BRAGA, José Carlos Souza. Temporalidade da riqueza: teoria da dinâmica e financeirização do capitalismo. Campinas, SP: Unicamp/IE, 2000.

BRUNHOFF, Suzanne de. La monnaie chez Marx. Paris: Éditions Sociales, 1976.

- Marx à Ricardien: valeur, monnaie et prix au début du capital. In: ed. par C. BERTHOMIEU, C. ; CARTELIER, L. (Ed.). Ricardiens, Keynésiens et Marxistes: essais en économie politique non-neoclassique. Nice: Les Presses Universitaires de Grenoble, 1972. p. 195-207.

CARCANHOLO, Reinaldo A. O capital especulativo e a desmaterialização do dinheiro. Revista da Sociedade Brasileira de Economia Política (SEP), Rio de Janeiro, 7 Letras, ano 6, n. 8, p. 26-45, 2001.

(Org.). Capital: essência e aparência. São Paulo: Expressão Popular, 2011. v. 1.

; NAKATANI, Paulo. O capital especulativo parasitário: uma precisão teórica sobre o capital financeiro, característico da globalização. Ensaios FEE, Porto Alegre, v. 20, n. 1, p. 264-304, jun. 1999. Disponível em: http://revistas.fee.tche.br/index.php/ensaios/issue/view/105.

;___ Capital fictício e lucros fictícios. Revista da Sociedade Brasileira de Economia Política (SEP). Rio de Janeiro, n. 24, p. 41-65, jun. 2009.

; Sobre o capital e a mais-valia. In: CARCANHOLO, Reinaldo A.

(Org.). Capital: essência e aparência. São Paulo: Expressão Popular, 2011. v. 1.

CORAZZA, Gentil. Notas teóricas sobre as relações real-monetário em Marx. In: JORNADA DE ECONOMIA POLÍTICA, SEP, 2, 1999. Anais...

GERMER, Claus M. Dinheiro, capital e dinheiro de crédito - o dinheiro segundo Marx. Tese (Doutoramento)-Instituto de Economia, Unicamp, 1995.

HARVEY, David. Los límites del capitalismo y la teoría marxista. México: Fondo de Cultura Econômica, 1990

. Condição pós-moderna: uma pesquisa sobre as origens da mudança cultural. 6. ed. São Paulo: Edições Loyola, 1996.

HILFERDING, Rudolf. O capital financeiro. São Paulo: Nova Cultural, 1985.

HOBSON, John. A evolução do capitalismo moderno: um estudo da produção mecanizada. São Paulo: Abril Cultural, 1983.

KATZ, Claudio. Enigmas contemporâneos de las finanzas y la moneda. Ciclos en la Historia, la Economia y la Sociedad, año XII, v. XII, n. 23, p. 191-219, 2002. 
KLAGSBRUNN, Vitor H. Considerações sobre a categoria dinheiro de crédito. Ensaios FEE, Porto Alegre, v. 13, n. 2, p. 592-615, 1992.

LÉNINE, Vladimir I. L’impérialisme, stade suprême du capitalisme. Oeuvres choisies. Moscou: Éditions en Langues Étrangers, tome I, deuxième partie, p. 433-572, 1954.

MANDEL, Ernest. Traité d'économie marxiste. Paris: Éditions René Julliard, tome II, p. 55-109, 1962.

MARX, Karl. Le Capital. Paris: Éditions Sociales, 1948. livre I, tome I. Le Capital. Paris: Éditions Sociales, 1978. livre III, tome II. . O Capital. São Paulo: Abril Cultural, 1983. v. I, tomo I. . O Capital. São Paulo: Abril Cultural, v1984a. v. I, tomo II. . O Capital. São Paulo: Abril Cultural, 1984b. v. II. . O Capital. São Paulo: Abril Cultural, 1984c. v. III, tomo I. . O Capital. São Paulo: Abril Cultural, 1985. v. III, tomo II. . Théories sur la plus-value. Paris: Éditions Sociales, 1976. tome III, p. 535-635. . Salaire, prix et profit. Paris: Éditions Sociales, 1969. . Manuscrits de 1857-1858 (Grundrisse). Paris: Éditions Sociales, 1980. tome I. - Manuscrits de 1844 (économie politique et philosophie). Paris: Éditions Sociales, (Le pouvoir de l'argent dans la société bourgeoise), 1972. p. 53-65.

MOLLO, Maria de Lourdes Rollemberg. Monnaie, valeur et capital fictif. Tese (Doutorado)-Université Parix X, Paris, 1989.

PERLO, Victor. L'empire de la haute finance: la genèse du capitalisme monopoliste d'état aux USA. Paris: Éditions Sociales, 1974. p. 7-182.

PINTO, Nelson Prado A. O capital financeiro na economia contemporânea: uma revisão teórica e histórica de seu papel no desenvolvimento recente dos Estados Unidos. Tese (Doutorado)-Instituto de Economia, Unicamp, Campinas (SP), 1994.

ROBINSON, Joan. Essai sur l'économie de Marx. Paris : Éditions Dunod, p.1-18, 1971.

ROSDOLSKY, Roman. Gênese e estrutura de O Capital de Karl Marx. Rio de Janeiro: EDUERJ: Contraponto, 2001.

ROUBINE, Isaak I. Essais sur la théorie de la valeur chez Marx. Paris : Éditions Maspero, 1978.

RIBEIRO, Nelso R. O capital em movimento: ciclos, rotação, reprodução. João Pessoa (PB): Editora Universitária da UFPb, 2009. 
SABADINI, Mauricio de Souza. Le capital fictif et ses effets sur la macroéconomie et sur le monde du travail au Brésil. Tese (Doutorado)-Université Paris 1 - Panthéon Sorbonne, Centre d'Économie de la Sorbonne (CES), Paris, 2008. Disponível em: http://tel.archivesouvertes.fr/tel-00354467/en/.

Sobre o conceito de capital financeiro (I). In: ENCONTRO NACIONAL DE ECONOMIA POLÍTICA (SEP), 17, jun. 2012. Anais...

SCHUMPETER, Joseph A. Théorie de l'évolution économique. Paris : Éditions Sociales, 1985. p. 107-143. 